UDC 531; 51-7 Вестник СПбГУ. Прикладная математика. Информатика... 2018. Т. 14. Вып. 2 MSC 92C10, 76Z99, 74F10

\title{
Mathematical modelling of pulsative blood flow in deformable arteries
}

\section{P. Tregubov, S. V. Rutkina}

St. Petersburg State University, 7-9, Universitetskaya nab., St. Petersburg, 199034, Russian Federation

For citation: Tregubov V.P., RutkinaS. V. Mathematical modelling of pulsative blood flow in deformable arteries. Vestnik of Saint Petersburg University. Applied Mathematics. Computer Science. Control Processes, 2018, vol. 14, iss. 2, pp. 158-164. https://doi.org/10.21638/11702/ spbu10.2018.208

The comprehensive analysis of structure and properties was performed for the blood and blood vessels. This analysis shows that the blood may be considered as a liquid only in large and middle vessels, where a diameter of vessel is much more than a dimension of blood cells and their aggregates. In addition, taking into account the influence of complex internal structure on its mechanical properties, it is necessary to consider it as a non-Newtonian liquid. In this regard, the non-Newtonian liquid with the power connection of the stress tensor with the strain velocity tensor was chosen for mathematical modelling of liquid. The pulsating flow is created by the pulsating nature of the boundary condition for the blood flow at the input cross-section. The vessels are considered as thick-walled cylinders with hyperelastic walls. The interaction between blood and vessel wall is defined by means of semi-slip boundary condition. Computer simulation was performed in software complex ANSYS with the use of the direct conjugating module CFX and the module ANSYS "Multiphysics". As a result, the pressure and stress wave propagation on the vessel wall was obtained.

Keywords: mathematical modelling, pulsating blood flow, non-Newtonian liquid, deformable blood vessels.

Introduction. One of the main difficulties, arising in computer simulation of haemodynamics, lies in an account of the complicated blood structure and mechanical properties. As is known, the blood consists of liquid plasma and deformable blood cells, which comprise up to $46 \%$ of the blood volume (Fig. 1), and their mechanical properties and inner structures are poorly studied.

The main part of blood cells (about 90\%) comprises erythrocytes. In blood flow they can create aggregates of column form, which also changes the flow pattern and its mechanical properties [1] (Fig. 2).

In essence, the blood is a suspension, having complicated and varied structure. In connection with this the consideration of blood as a two-phase medium contains significant simplifications [2, 3]. By this reason, first of all, the blood may be considered as a liquid only if the blood vessel diameter is much greater than dimensions of cells and their aggregates. Furthermore, since the presence of blood cells significantly influences its rheology and, as a consequence, affects the nature of the flow [4], blood may be considered only as nonNewtonian liquid that, in its turn, affects the nature of the flow [4]. The special attention was paid to this effect in [5]. It is also important to take into account the non-Newtonian blood properties in cases of vessel pathologies [6]. Effects of the non-Newtonian viscosity of blood on flow in diseased arterial vessels even for steady flows was underlined in [7].

Besides, due attention should be given to the pulse nature of blood flow in arteries, as it is shown in Fig. 3, which was obtained during the medical investigation of a patient.

(C) Санкт-Петербургский государственный университет, 2018 
Figure 1. The blood cells

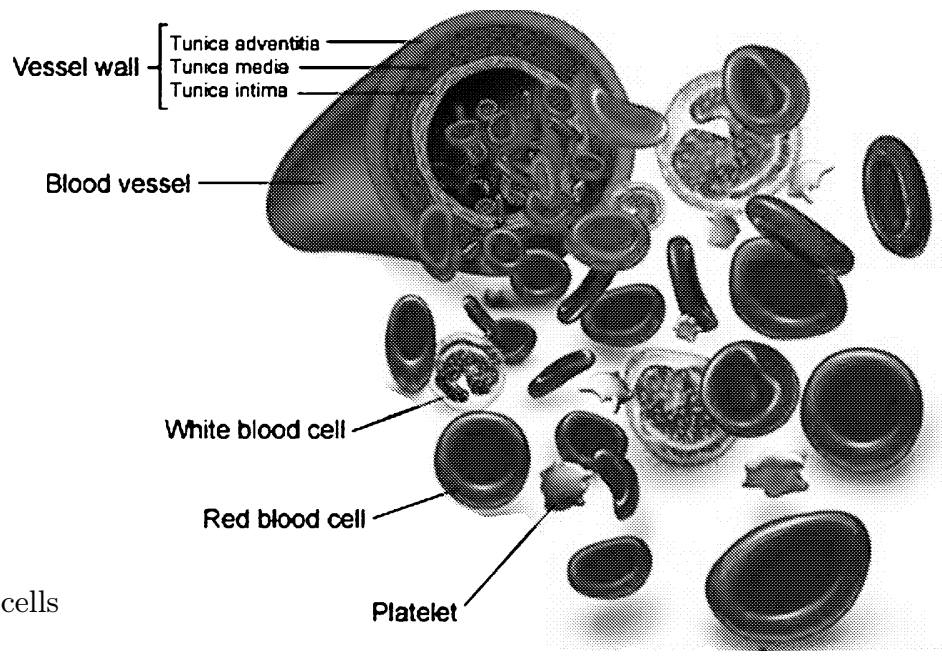

Figure 2. Formation

of the erythrocyte aggregates
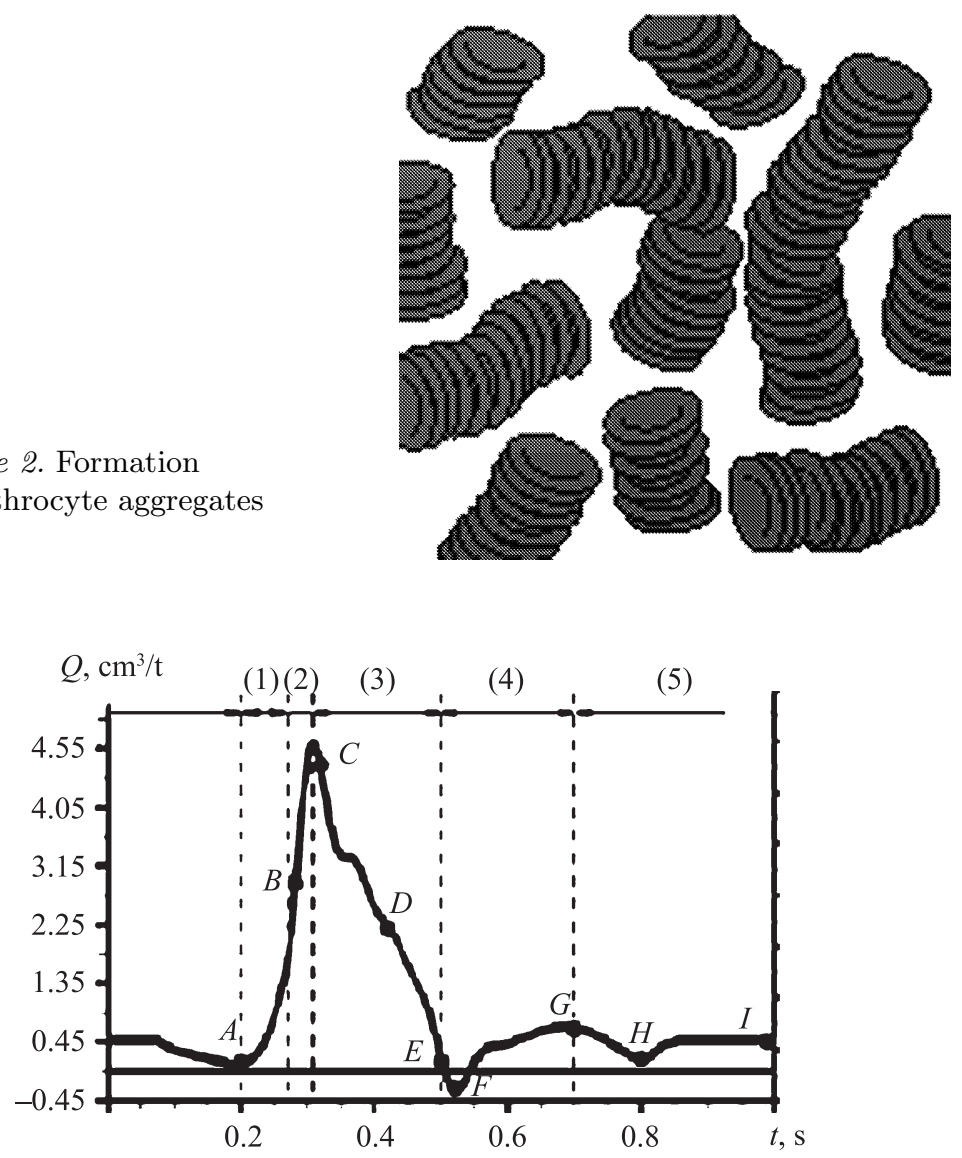

Figure 3. The variation of blood flow $Q$ with time $t$ at the entrance to the simulated artery section ( $A, B, C, D, E, F, G, H$ are the physiologically characteristic points of pulse wave) 
But as the vessel is further and further from the heart the pulse wave grows weaker and changes its form. This circumstance should be taken into account when using this characteristic as the boundary condition.

Another difficulty is the complicated vessel structure and insufficient knowledge of vessel mechanical properties, which are essential for their modelling and the and the subsequent hydroelastic setting of the "fluid-structure" problem. As a result, the authors are usually forced to use only simplified models.

In this connection it must be emphasized that this blood vessel property manifests in various degrees for different vessels.

Since the aorta is the most rigid vessel, its wall can be considered as undeformable [8-11]. However, the vessels which are located further from heart have deformable walls, and this should be taken into consideration (see, for example, [12]).

Of great importance is the interaction between the blood and the vessel wall. It should be noted that the "no-slip" condition, which is usually used as the boundary condition when solving problems of viscous liquid flow, is unacceptable for the adequate description of interaction between the blood and the vessel wall [13]. The matter is that the blood cells do not stick to a healthy vessel wall and slide along it due to their electrochemical properties. In this connection it would be appropriate to use the so-called "semi-slip" condition. The expediency of this condition application for smooth surfaces was pointed out in [14].

Mathematical model of blood. The blood was considered as a non-Newtonian liquid with Power law for correlation between the stress tensor and the strain velocity tensor, which can be written in the tensor form

$$
\boldsymbol{T}=2 k\left|I_{2}\right|^{\left(\frac{n-1}{2}\right)} \boldsymbol{D}
$$

where $\boldsymbol{T}$ is the viscous stress tensor, $\boldsymbol{D}$ is the strain velocity tensor and $I_{2}$ is its second principal invariant of $\boldsymbol{D}$. Having the expression of this power law the system of governing equations for the blood flow can be written as follows:

$$
\rho \frac{d \boldsymbol{v}}{d t}=\nabla(-p \boldsymbol{I}+\boldsymbol{T})
$$

here $\boldsymbol{v}$ is the velocity vector and $\boldsymbol{I}$ is the identity tensor. In addition to this, the equation of continuity should be written

$$
\operatorname{div} \boldsymbol{v}=0 .
$$

The rest state was chosen as the initial condition for the equations (1) and (2) with relationship (3), that is

$$
\left.\boldsymbol{v}\right|_{t=0}=0 \text {. }
$$

After the calculation process starts, it continues until reaching a steady state regime.

The boundary conditions were set in the following manner. At the input cross-section of the considered vessel part the pulsating blood flow was given as it is shown in Fig. 2 . The output cross-section is mentally placed so far that the velocity could be considered constant and would have only a longitudinal component $v$. The pressure is also constant, that is

$$
\left.v\right|_{\text {output }}=\text { const, }\left.p\right|_{\text {output }}=\text { const. }
$$

Since, while moving through the vessel the blood cells do not adhere to the vessel wall, the no-slip condition, which is usually used for viscous liquid flows through pipes, 
is unacceptable for blood flow through the vessels. Because of this, the so called semislip condition was suggested to use. In this case the longitudinal component of velocity decreases to a certain preassigned value $v_{0}$ (Fig. 4), which is the boundary condition at the wall:

$$
v\left(r_{0}, \phi, t\right)=v_{0}
$$

The degree of semi-slip is usually defined by the parameter $b$.

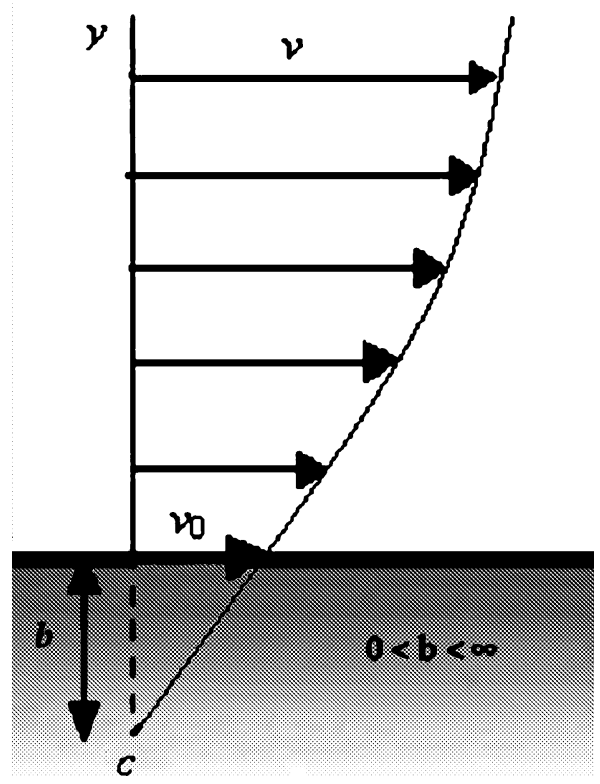

Figure 4. The velocity profile of blood flow between vessel axis and vessel wall in the case of semi-slip condition

Mathematical model of blood vessel. Blood vessels are considered as the thickwalled cylinders. The wall material is hyperelastic orthotropic and incompressible. In this case the wall's mechanical properties are described by the specific deformation energy $W$. The equations of the vessel wall motion can be written in the form

$$
\begin{aligned}
& \rho \frac{\partial^{2} \boldsymbol{u}}{\partial t^{2}}-\nabla(\boldsymbol{F}(u) \boldsymbol{S}(u))=0, \\
& \operatorname{det} \boldsymbol{F}(u)=1, \\
& \boldsymbol{E}=\frac{1}{2} \boldsymbol{F}^{T} \boldsymbol{F}-\boldsymbol{I}, \\
& \boldsymbol{S}=\frac{\partial W(\boldsymbol{E})}{\partial \boldsymbol{E}},
\end{aligned}
$$

where $\boldsymbol{u}$ is the wall displacement vector; $\rho$ is the density of the wall material; $\boldsymbol{F}$ is the deformation gradient; $\boldsymbol{S}$ is the second Piola-Kirchhoff stress tensor; $\boldsymbol{E}$ is the Green strain tensor. The boundary conditions which connect the movements of the blood and wall with regard to semi-slip condition are as follows: 


$$
\begin{aligned}
& \left.v\right|_{\text {wall }} \cdot \boldsymbol{n}=-\left.b\left(\frac{\partial u}{\partial t}\right)\right|_{\text {wall }} \cdot \boldsymbol{n}, \\
& \left.v\right|_{\text {wall }} \cdot \boldsymbol{\tau}=\left.\left(\frac{\partial u}{\partial t}\right)\right|_{\text {wall }} \cdot \boldsymbol{\tau}, \\
& \left.\sigma\right|_{\text {wall }} \cdot \boldsymbol{n}=-\left.(F(u) S(u))\right|_{\text {wall }} \cdot \boldsymbol{n}, \\
& \left.\sigma\right|_{\text {wall }} \cdot \boldsymbol{\tau}=-\left.(F(u) S(u))\right|_{\text {wall }} \cdot \boldsymbol{\tau},
\end{aligned}
$$

here $\boldsymbol{n}$ and $\boldsymbol{\tau}$ are the normal and tangent vectors of boundary, and $v$ and $\sigma$ are the blood velocity and stress on the wall. The stress normal component at the external wall boundary was taken equal zero.

Calculations. Calculations were performed in software complex ANSYS with the use of direct conjugating program modul CFX, destined for the liquid flow simulation, and the module ANSYS "Multiphysics", destined for simulation of the stress-strain state. For this purpose, the three space models of blood vessels were constructed with the help of computer program CAD and then were passed into ANSYS ICEM CFD for the construction of the three-space hexagonal deformable mesh with concentration near the wall. Exchange of the information between modules CFX and "Multiphysics" takes place at each time step, as it is shown in Fig. 5.

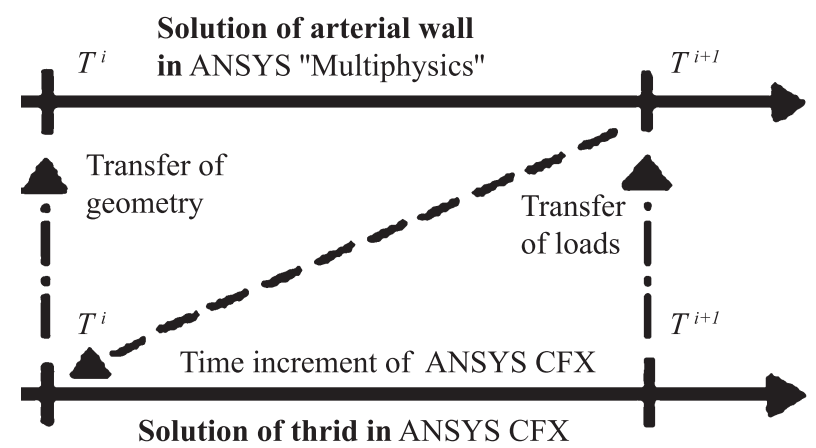

Figure 5. The diagram of interaction between modules ANSYS CFX and ANSYS "Multiphysics"

Results. As a result, the pressure wave propagation in the vessel and stress wave propagation in vessel wall together with the vessel strain during the pulse wave passage were obtained. The examples are shown in Figs 6 and 7 .

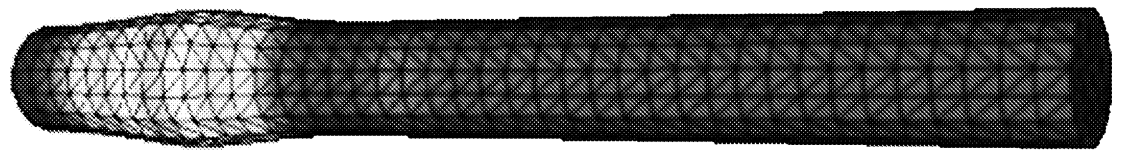

Figure 6. The pressure wave propagation in the vessel

Discussion. Thus, the model of pulsating flow in the artery with deformable wall was developed. Two principal positions were used as a basis for computer simulation: the mechanical models of blood and blood vessel. The blood was considered as non-Newtonian liquid with Power law for correlation between the stress tensor the strain velocity tensor. 


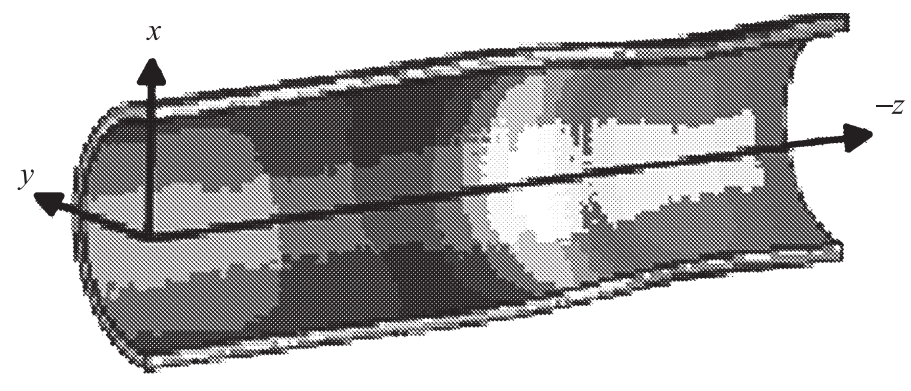

Figure $\%$. The stress wave propagation in the vessel wall

This law contains two parameters $n$ and $k$, which are usually consider as constant. In fact, they can vary along the stream and cross-section, but the nature of this change has not been adequately studied. There are reasons to assume that these constants depend on hematocrit [15], but there are only assumptions of specific kind of this dependence.

It is necessary to point out impossibility to develop the vessel mechanical model considering the inner structure of its wall. By this reason, the authors are forced to use averaged properties and consider the wall material as hyperelastic orthotropic and incompressible, although this variant is not unique.

In general, it is necessary to ascertain that the main obstacle on the way of computer simulation of medico-biological objects and processes is not absence of mathematical instrument and computer technologies but deficiency of physiological knowledge and specific data, which are required for construction the more adequate models.

\section{References}

1. Schmid-Schonbein H. Rheological properties of human erythrocytes and their influence upon anomalous viscosity of blood. Physiol. Rev., 1971, vol. 63, pp. 14-219.

2. Jung J., Lyczkowski R. W., Panchal C. B., Hassanein A. Multiphase haemodynamics simulation of pulsative flow in a coronary artery. J. Biomechanics, 2006, vol. 39, no. 20, pp. 64-73.

3. Srivastava V. P. Two-phase model of blood flow through stenosed tubes in the presence of a peripheral layer: applications. J. Biomechanics, 1996, vol. 29, pp. 1377-1382.

4. Gijsen F. G. H., Allanic E., Van De Vosse F. N., Janssen J. D. The influence of the nonNewtonian properties of blood on the flow in large arteries: unsteady flow in a 900 curved tube analysis. J. Biomechanics, 1999, vol. 32, pp. 705-713.

5. Baskurt O. K., Meiselman H. J. Blood rheology and haemodynamics. Seminars in thrombosis and hemostasis, 2003, vol. 29(5), pp. 435-450.

6. Tregubov V.P., Zhukov N.K. Computer simulation of the blood stream with availability of vessel pathologies. Russian J. Biom, 2017, vol. 2, pp. 201-210.

7. Cho Y. I., Kensey K. R. Effects of the non-Newtonian viscosity of blood on flows in a diseased arterial vessel. Pt 1. Steady Flows. Biorheology, 1991, vol. 28, pp. 241-262.

8. Tokuda Y., Song M. H., Ueda Y., Usui A., Akita T., Yoneyama S., Maruyama S. Three-dimensional numerical simulation of blood flow in the aortic arch during cardiopulmonary bypass. Europ. J. Cardiothoracic Surgery, 2008, vol. 33, pp. 164-167.

9. Numata S., Itatani K., Kanda K., Doi K., Yamazaki S., Morimoto K., Manabe K., Ikemoto K., Yaku H. Blood flow analysis of the aortic arch using computational fluid dynamics. Europ. J. CardioThoracic Surgery, 2016, vol. 49(6), pp. 1-8.

10. Tregubov V. P. Mathematical modelling of the non-Newtonian blood flow in the aortic arc. Computer Research and Modeling, 2017, vol. 9(2), pp. 259-269.

11. Tregubov V., Mukhtarova D. A model study of blood flow in branching vessels. Vestnik of Saint Petersburg University. Series 10. Applied Mathematics. Computer Science. Control Processes, 2017, vol. 13 , iss. 1, pp. $42-50$.

12. Duta A., Tarbell J. M. Influence of non-Newtonian behavior of blood on flow in elastic artery mofel. J. Biomech. Eng., 1996, vol. 118, pp. 111-119. 
13. Zhu Y., Granick S. Limits of hydrodynamic no-slip boundary condition. Phys. Review Letters, 2002, vol. 88, pp. 102-106.

14. Zhu Y., Granick S. Rate-dependent slip of Newtonian liquid at smooth surfaces. Phys. Review Letters, 2001, vol. 87, pp. 96-105.

15. Bessonov N., Sequeira A., Simakov S., Vassilevskji Yu., Volpert V. Methods of blood flow modeling. Math. Mod. Nature Phenomena, 2016, vol. 11(1), pp. 1-25.

Recommendation: prof. L. A. Petrosyan.

Received: 23.10.2017; accepted: 15.03.2018.

Author's Information:

Tregubov Vladimir P. - Dr. Sci. in physics and mathematics, professor; v.tregubov@spbu.ru

Ratkina Svetlana V. - master, svet.ratkina@yandex.ru

\section{Математическое моделирование пульсирующего течения крови в деформируемых артериях}

\section{В. П. Трегубов, С. В. Раткина}

Санкт-Петербургский государственный университет, Российская Федерация, 199034, Санкт-Петербург, Университетская наб., 7-9

Для цитирования: Трегубов В. П., Раткина С. В. Математическое моделирование пульсирующего течения крови в деформируемых артериях // Вестник Санкт-Петербургского университета. Прикладная математика. Информатика. Процессы управления. 2018. Т. 14. Вып. 2. C. 158-164. https://doi.org/10.21638/11702/spbu10.2018.208

В статье приводится анализ структуры и механических свойств крови и кровеносных сосудов. Он показывает, что кровь можно считать жидкостью только в крупных и средних сосудах, где диаметр сосуда много больше размера клеток крови и их агрегатов. Кроме того, принимая во внимание влияние сложной внутренней структуры крови на ее механические свойства, кровь необходимо моделировать неньютоновской жидкостью. В связи с этим для моделирования крови выбрана неньютоновская жидкость со степенной связью тензора напряжений с тензором скоростей деформаций. Пульсирующий поток для этой модели крови формируется за счет пульсирующего характера входного граничного условия. Кровеносные сосуды рассматриваются как тонкостенные цилиндры с гиперэластичными стенками. Взаимодействие потока крови со стенками сосуда осуществляется в соответствии с режимом полупроскальзывания. Компьютерная реализация предложенной модели потока крови была выполнена при помощи пакета ANSYS с использованием метода расщепления с последующим прямым сопряжением модуля CFX и модуля ANSYS "Multiphysics". В результате были получены напряжения и деформации на стенке сосуда при прохождении пульсовой волны.

Ключевые слова: математическое моделирование, пульсирующий поток крови, неньютоновская жидкость, деформируемые кровеносные сосуды.

Контактная информация:

Трегубов Владимир Петрович - докт. физ.-мат. наук, професcop; v.tregubov@spbu.ru Раткина Светлана Викторовна - магистр; svet.ratkina@yandex.ru 